\title{
Tau Immunotherapy Modulates Both Pathological Tau and Upstream Amyloid Pathology in an Alzheimer's Disease Mouse Model
}

\author{
Diana L. Castillo-Carranza, ${ }^{1,2,3}$ Marcos J. Guerrero-Muñoz, ${ }^{1,2,3}$ Urmi Sengupta, ${ }^{1,2,3}$ Caterina Hernandez, ${ }^{1,2,3}$ \\ Alan D.T. Barrett, ${ }^{4}$ Kelly Dineley, ${ }^{1,2,3}$ and Rakez Kayed ${ }^{1,2,3,4}$ \\ ${ }^{1}$ Mitchell Center for Neurodegenerative Diseases, Departments of ${ }^{2}$ Neurology, ${ }^{3}$ Neuroscience and Cell Biology, and ${ }^{4}$ Sealy Center for Vaccine Development, \\ University of Texas Medical Branch, Galveston, Texas 77555
}

\begin{abstract}
In Alzheimer's disease $(\mathrm{AD})$, the pathological accumulation of tau appears to be a downstream effect of amyloid $\beta$ protein $(\mathrm{A} \beta)$. However, the relationship between these two proteins and memory loss is unclear. In this study, we evaluated the specific removal of pathological tau oligomers in aged Tg2576 mice by passive immunotherapy using tau oligomer-specific monoclonal antibody. Removal of tau oligomers reversed memory deficits and accelerated plaque deposition in the brain. Surprisingly, $A \beta^{\star} 56$ levels decreased, suggesting a link between tau and $\mathrm{A} \beta$ oligomers in the promotion of cognitive decline. The results suggest that tau oligomerization is not only a consequence of $A \beta$ pathology but also a critical mediator of the toxic effects observed afterward in AD. Overall, these findings support the potential of tau oligomers as a therapeutic target for AD.
\end{abstract}

Key words: $\mathrm{A} \beta{ }^{\star} 56$; Alzheimer’s disease; immunotherapy; Tau oligomers; Tg2576

\section{Introduction}

In Alzheimer's disease (AD), amyloid plaques and neurofibrillary tangles (NFTs) are considered responsible for disease progression (Selkoe, 2001). Although amyloid pathology lies upstream of, or parallel to, tau pathology (Oddo et al., 2003; Small and Duff, 2008), current evidence suggests that tau is a direct casual mediator of amyloid $\beta$ protein $(\mathrm{A} \beta$ ) toxicity (Rapoport et al., 2002; Roberson et al., 2007; Nussbaum et al., 2012; Bloom, 2014). Furthermore, it is well established that aggregated $\mathrm{A} \beta$ is an important contributor to tau phosphorylation, mislocalization, and aggregation in animal models and cell cultures (Busciglio et al., 1995; Götz et al., 2001; Ferrari et al., 2003; De Felice et al., 2008; Ittner et al., 2010). Growing evidence implicates small soluble oligomeric assembles of misfolded amyloids as critical pathogenic species (Haass and Selkoe, 2007; Lasagna-Reeves et al., 2011 a; CastilloCarranza et al., 2013a,b). Consequently, it seems likely that $\mathrm{A} \beta$ oligomers, but not the fibrillar form of $\mathrm{A} \beta$, induced tau hyperphosphorylation (De Felice et al., 2008) and neuritic degenera-

\footnotetext{
Received Dec. 8, 2014; revised Feb. 4, 2015; accepted Feb. 17, 2015.

Author contributions: D.L.C.-C., A.D.T.B., K.D., and R.K. designed research; D.L.C.C., M.J.G.-M., U.S., and C.H. performed research; D.L.C.-C., M.J.G.-M., U.S., C.H., K.D., and R.K. analyzed data; D.L.C.-C., A.D.T.B., K.D., and R.K. wrote the paper.

This work was supported in part by the Cullen Trust, the Alzheimer's Drug Discovery Foundation, the Mitchell Center for Neurodegenerative Disease, the Sealy Center for Vaccine Development, and the Moody Project for Translational Traumatic Brain Injury. We thank Prof. Yogesh Wairkar for his valuable assistance with this project and Dr. Adriana A. Paulucci-Holthauzen for her technical assistance with the confocal microscopy. A special thanks to Jennifer Deger and Prof. Bridget E. Hawkins for contributing to the editing process.

R.K. has patent applications on the compositions and methods related to tau oligomers and antibodies.

Correspondence should be addressed to Dr. Rakez Kayed, 301 University Boulevard, Medical Research Building, Room 10.138C, Galveston, TX 77555-1045. E-mail: rakayed@utmb.edu.

DOI:10.1523/JNEUROSCI.4989-14.2015

Copyright $\odot 2015$ the authors $\quad 0270-6474 / 15 / 354857-12 \$ 15.00 / 0$
}

tion (Jin et al., 2011) in cells overexpressing human tau and in mice overexpressing human wild-type (WT) tau (Chabrier et al., 2012).

In addition, $\mathrm{A} \beta$ oligomers seeds tau oligomerization (LasagnaReeves et al., 2010). The formation of tau oligomers is a significant event in tau aggregation because these structures are highly toxic and cause synaptic and mitochondrial dysfunction, display potent amnestic effects in vivo, and propagate effectively in WT mice (Lasagna-Reeves et al., 2011b, 2012b).

Despite clear demonstration of $\mathrm{A} \beta$ and tau oligomer toxicity in vitro and in vivo (Kayed et al., 2003; Glabe and Kayed, 2006; Lasagna-Reeves et al., 2012a,b), the underlying mechanism of toxicity and the relationship of tau to $\mathrm{A} \beta$ remains unclear.

To investigate the relationship between the formation of tau oligomers, $\mathrm{A} \beta$ toxicity, and $\mathrm{AD}$-related phenotypes, we analyzed one of the most extensively studied $\mathrm{AD}$ models, the transgenic $\mathrm{APP}_{\mathrm{K} 670 \mathrm{~L}, \mathrm{M} 671 \mathrm{~N}} \mathrm{Tg} 2576$ mouse that is characterized by the overproduction and deposition of $\mathrm{A} \beta$ protein (Hsiao et al., 1996). Similar to other amyloid precursor protein (APP) models, the Tg2576 exhibits hyperphosphorylated tau, but it does not develop NFTs (Sturchler-Pierrat et al., 1997; Maia et al., 2013). Here we demonstrate that, in this mouse model, tau oligomerizes in an age-dependent manner that coincides with the appearance of $A \beta$ oligomers and declining cognitive function (Kawarabayashi et al., 2001; Westerman et al., 2002; Ashe, 2006; Lesné et al., 2006). To further investigate the role of tau oligomers in phenotypes seen in aged Tg2576 animals, we treated 14-month-old mice with antitau oligomer-specific monoclonal antibody (TOMA) (CastilloCarranza et al., 2014a,b) and found that targeting tau oligomers improved cognitive performance and increased plaque deposition in the brain. Collectively, our findings highlight a mechanistic interac- 
tion between $\mathrm{A} \beta$ and tau oligomers and reinforce the concept of pathologic tau as a therapeutic target for $\mathrm{AD}$.

\section{Materials and Methods}

Animals. This study was conducted in a facility approved by the American Association for the Accreditation of Laboratory Animal Care, and all experiments were performed in accordance with the National Institutes of Health Guide for the Care and Use of Laboratory Animals and approved by the Institutional Animal Care and Use Committee of the University of Texas Medical Branch (UTMB). All animals used here were male to control for changes in female hormone state that may affect cognitive data. Tg2576 mice and the nontransgenic littermate (WT) animals were bred at UTMB free of enrichment to prevent any effect on behavioral test performance. Mice were housed at the UTMB animal care facility and maintained according to U.S. Department of Agriculture standards ( $12 \mathrm{~h}$ light/dark cycle with food and water available ad libitum).

Immunization scheme. The 14-month-old Tg2576 and WT mice $(n=$ 12-14 animals per group) were given intravenous injections of $30 \mu \mathrm{g} /$ animal of TOMA or $30 \mu \mathrm{g}$ of anti-Rhodamine antibody (IgG, nonspecific; Rhodamine; catalog \#GTX29093; Genetex) for the control treatment group (IgG group). For intravenous injections, mice were placed in a restrainer (Braintree Scientific), and an inch of the tail was shaved and placed in warm water to dilate veins. Mice were then injected via the lateral tail vein, returned to home cages, and kept under observation.

Behavioral analyses. To determine the effect of immunotherapy on behavioral deficits, the cognition of $\mathrm{Tg} 2576$ mice was evaluated by using the novel object recognition (NOR) test and the fear conditioning (FC) test. Before performing the behavioral test, mice were habituated to frequent experimenter handling. The NOR test was performed 2 weeks after immunization, followed by the FC test.

NOR test. The NOR test evaluates the natural tendency of rodents to preferentially explore novel objects (NOs) and environments over those that are familiar. This task has been used previously to detect memory impairment in $\operatorname{Tg} 2576$ mice. The first day of the test, mice were habituated to an open field. Mice were allowed to freely explore a white openfield arena ( $55 \mathrm{~cm}$ diameter $\times 60 \mathrm{~cm}$ height) for $15 \mathrm{~min}$. The next day, mice were placed in the arena for a training phase with two identical objects, either spheres or cubes, and allowed to explore for $15 \mathrm{~min}$. On the third day, mice were returned to the arena for $15 \mathrm{~min}$ with one familiar object (FO) explored previously in the training phase and one NO differing in color and shape but sharing a common size and volume. After each trial, the apparatus was cleaned thoroughly using $70 \%$ ethanol and allowed to dry before placement of a new mouse. Trials were recorded, and the time spent exploring each object was measured using ANY-Maze software (Stoelting). Exploration was defined by head orientation within $2 \mathrm{~cm}$ of the object or physical contact with the object. The percentage of total time spent exploring the FO versus the NO was measured. To control for any differences in exploratory behavior, the discrimination index was also calculated as the time spent exploring the FO subtracted from the time spent exploring the NO, divided by the total time spent exploring both objects. Object exploration data were analyzed using Prism 5.04 software (GraphPad Software).

FC. The test was performed as we described previously (Dineley et al., 2002). Briefly, the training phase consisted of placing the mice in a particular environment [a training chamber with particular lighting, geometry, and odor that constitutes the context conditioned stimulus (CS)] and allowed to explore for $3 \mathrm{~min}$. An auditory CS ( $80 \mathrm{~dB}$ white noise) was then presented for $30 \mathrm{~s}$, and one footshock [0.8 mA, $2 \mathrm{~s}$ duration; the unconditioned stimulus (US)] was delivered during the last $2 \mathrm{~s}$ of the auditory CS. A second presentation of the auditory CS and the US was delivered at the $5 \mathrm{~min}$ mark, and the animals were then left in the cage for another $2 \mathrm{~min}$. Twenty-four hours later, the mice were returned to the same training chamber, and the context test for fear learning was performed. The amount of freezing that the mice exhibited during 5 min in the training chamber was measured. Six hours later, the cued test was performed in a completely novel context. The animals were placed in the testing chamber, freezing was measured for $3 \mathrm{~min}$ before the auditory CS was re-presented, and freezing was quantified over the next 3 min.

Tissue harvesting. After behavioral testing, animals were killed with $\mathrm{CO}_{2}$, and brains were collected. The left hemisphere was embedded in paraffin and sectioned. The right hemisphere was processed immediately for biochemical analysis. Briefly, frozen brains were diced and homogenized in phosphate buffered saline with a protease inhibitor mixture (Roche) and $0.02 \% \mathrm{NaN} 3$ using a 1:3 (w/v) dilution. Samples were then centrifuged at $10,000 \mathrm{rpm}$ for $10 \mathrm{~min}$ at $4^{\circ} \mathrm{C}$. The supernatants were divided into aliquots, snap-frozen, and stored at $-80^{\circ} \mathrm{C}$ until use (Castillo-Carranza et al., 2014b).

Western blot analysis. Each lane was loaded with 20-25 $\mu \mathrm{g}$ of total protein from one sample on precast NuPAGE $4-12 \%$ Bis-Tris Gels for SDS-PAGE (Invitrogen) and subsequently transferred onto nitrocellulose membrane. After blocking overnight at $4^{\circ} \mathrm{C}$ with $10 \%$ nonfat dried milk, membranes were probed for $1 \mathrm{~h}$ at room temperature with TOMA (1:350), T22 (1:350), Tau 5 (1:1000; Covance), Fyn (1:700; Santa Cruz Biotechnology), glycogen synthase kinase- $3 \beta$ enzyme (GSK3 $\beta$; 1:1000; Thermo Fisher Scientific), OC (1:1000), 6E10 (1:1000; Covance), and actin (1:1000; Thermo Fisher Scientific) and then diluted in 5\% nonfat dried milk. T22 and OC were detected with horseradish peroxidase (HRP)-conjugated anti-rabbit IgG (1:3000; GE Healthcare). TOMA, Tau 5 , GSK3 $\beta, 6 \mathrm{E} 10$, and actin antibody detection was done with HRPconjugated IgG anti-mouse secondary antibody (1:3000; GE Healthcare). ECL Plus (GE Healthcare) was used for signal generation. For protein quantification, the densitometry of each band was measured using Labworks 4.5 software (UVP) and normalized with actin. All densitometry results represent the mean \pm SD.

Dot blot analysis. Dot blot strips were prepared on nitrocellulose membranes. Briefly, $0.5-1.2 \mu \mathrm{l}$ of each sample was applied onto the strips and blocked with $10 \%$ nonfat dried milk in $1 \times$ tris buffered saline with Tween 20 (TBST) buffer, $\mathrm{pH} 7.4$, overnight at $4^{\circ} \mathrm{C}$. The strips were washed once with $1 \times$ TBST buffer and incubated with Tau 5 (1:1000) and $\mathrm{A} \beta_{1-42}$ (1:100; Calbiochem) for $1 \mathrm{~h}$ at room temperature. The strips were washed three times with $1 \times$ TBST and then incubated with HRPconjugated IgG anti-mouse secondary antibody (1:3000; GE Healthcare) or HRP-conjugated anti-rabbit IgG (1:3000; GE Healthcare), respectively, for $1 \mathrm{~h}$ at room temperature. Finally, the membranes were washed three times with $1 \times$ TBST and developed using ECL plus chemiluminiscence kit (GE Healthcare). Dot quantification was performed using Labworks 4.5 software (UVP).

Immunoprecipitation. Tau oligomers were coimmunoprecipitated (co-IP) using T22 antibody. An unrelated antibody was used as a control for the nonspecific immunoprecipitation of tau and $\mathrm{A} \beta$ peptide (antiRhodamine antibody). co-IP was performed following the recommendations of the manufacturer (catalog \#23600; Thermo Fisher Scientific). Briefly, $1 \mathrm{mg}$ of antibody was immobilized in $200 \mu \mathrm{l}$ of resin for $2 \mathrm{~h}$ at room temperature. Brain tissue was homogenized in $1 \times$ PBS. Brain lysates were pre-adsorbed in a control resin to eliminate unspecific protein binding. Flow-through samples were incubated with the antibodycoupled resin in an end-over mixing for $2 \mathrm{~h}$. Antibody-bound proteins were recovered using $50 \mu \mathrm{l}$ of elution buffer. Samples were applied immediately into nitrocellulose membrane to perform a dot blot analysis. Remaining samples were frozen and stored at $-80^{\circ} \mathrm{C}$.

ELISA. ELISA plates were coated with $15 \mu \mathrm{l}$ of brain PBS-soluble fraction using $0.05 \mathrm{M}$ sodium bicarbonate, $\mathrm{pH}$ 9.6, as coating buffer and incubated overnight at $4^{\circ} \mathrm{C}$. Plates were washed one time with $1 \times \mathrm{TBST}$ (containing $0.01 \%$ Tween 20 ), followed by blocking for $2 \mathrm{~h}$ at room temperature with $10 \%$ nonfat dry milk in TBST. The plates were then washed one time with $1 \times$ TBST. TOMA (1:250), T22 (1:250), Tau 5 (1:1000), 6E10 (1:1000), OC (1:1000), A11 (1:700), or 4G8 (1:1000) antibody diluted in 5\% nonfat milk in TBST was then added and allowed to react for $1 \mathrm{~h}$ at room temperature. The plates were then washed three times with $1 \times$ TBST. T22, OC, and A11 immunoreactivity was detected using $100 \mu \mathrm{l}$ of HRP-conjugated anti-rabbit IgG (GE Healthcare), and TOMA, Tau5, 6E10, and 4G8 were detected using HRP-conjugated antimouse IgG (GE Healthcare). The secondary antibody (diluted 1:3000 in $5 \%$ nonfat milk in $1 \times$ TBST) was added, followed by incubation for $1 \mathrm{~h}$ at room temperature. Finally, plates were washed three times with $1 \times$ 
TBST and incubated with $100 \mu \mathrm{l}$ of 3,3,5,5- tetramethylbenzidine (TMB-1 component substrate; Dako) for $1 \mathrm{~h}$ in the dark. The reaction was stopped with $100 \mu \mathrm{l}$ of $2 \mathrm{M} \mathrm{HCl}$, and the plates were read at $450 \mathrm{~nm}$ in a Polar Star Omega plate reader (BMG Labtech). To evaluate the levels of inflammation markers IL-1 and IL-6, brain homogenates were analyzed using the ELISA kits (EM2IL6 and EM2ILB; Pierce). Briefly, samples were incubated on plates precoated with biotinylated antibodies against IL-1 and IL-6 for $1 \mathrm{~h}$. After incubation with streptavidinHRP, tetramethylbenzidine chromogen was applied, as was the manufacturer supplied stop solution. The concentration of samples was determined at $450 \mathrm{~nm}$ and reported as optic density (OD) value.

Immunofluorescence. Immunohistochemistry was performed on paraffin sections. All sections were processed simultaneously under the same conditions. Brain sections were deparaffinized, rehydrated, and washed in $0.01 \mathrm{M}$ phosphate buffer three times ( $5 \mathrm{~min}$ each). After blocking in normal goat serum (Invitrogen) for $1 \mathrm{~h}$, sections were incubated overnight with TOMA (1:250) or T22 (1:350). The next day, the sections were washed in PBS three times (10 min each) and then incubated with goat anti-mouse IgG Alexa Fluor 568 (1:700; Invitrogen) or goat anti-rabbit IgG Alexa Fluor 568 (1:700; Invitrogen) for $1 \mathrm{~h}$. The sections were then washed three times (10 min each) in PBS before incubation overnight with 6E10 (1:500), OC (1:700), A11 (1:450), PSD95 (1:700), anti-mouse Lamp-2 (1:100; Abcam), or the microglial marker Iba-1 (1:500; Abcam). The next day, the sections were washed in PBS three times for 10 min each before incubation with goat anti-mouse IgG Alexa Fluor 488 (1:700; Invitrogen) or goat anti-rabbit IgG Alexa Fluor 488 (1:700; Invitrogen) for $1 \mathrm{~h}$. Sections were washed and mounted using Fluoromount G (Southern Biotech) mounting medium with DAPI (Invitrogen). The sections were examined using an epifluorescence microscope (Eclipse 800; Nikon) equipped with a CoolSnap-FX monochrome CCD camera (Photometrics) using standard Nikon FITC and DAPI filters. Images were analyzed using the Metavalue version 7.1 software (Molecular Devices). Confocal z-stack images were acquired using the Bio-Rad Radiance 2100 confocal system mounted on a Nikon Eclipse E800 microscope. To build the z-stack, 12 confocal planes/ $0.7 \mu \mathrm{m}$ thickness were captured.

Immunohistochemistry. Immunohistochemistry was performed on paraffin sections. In brief, paraffin sections $(8 \mu \mathrm{m})$ were deparaffinized and rehydrated. After blocking in normal goat serum for $1 \mathrm{~h}$, sections were incubated overnight with the primary antibodies TOMA (1:250) or OC (1:700). The next day, the sections were washed in PBS three times (10 min each) and then incubated with biotinylated goat anti-mouse IgG (1:2000; Jackson ImmunoResearch) or biotinylated goat anti-rabbit IgG (1:2000; Jackson ImmunoResearch) for $1 \mathrm{~h}$. The sections were then washed three times (10 min each) in PBS and visualized using an ABC reagent kit (Vector Laboratories) according to the recommendations of the manufacturer. Finally, sections were counterstained with hematoxylin (Vector Laboratories) for nuclear staining and mounted.

Golgi staining. Golgi staining was performed following the recommendation of the FD Rapid Golgi Stain kit (PK401; FD Neuro Technologies). Briefly, dissected mouse brains were incubated in Solutions A and B for 2 weeks at room temperature, followed by an incubation period in Solution $\mathrm{C}$ for $24 \mathrm{~h}$ at $4^{\circ} \mathrm{C}$. Stained sections were subjected to immunostain with OC before treatment with $70 \%$ formic acid (Sarsoza et al., 2009). Sections were imaged under a bright-field Eclipse 800 microscope equipped with a DXM1200 color CCD camera (both from Nikon). Dendritic segments from the cortex were selected randomly for spine analysis. Quantitation of spines in $10 \mu \mathrm{m}$ segments was performed using $\mathrm{NIH}$ ImageJ software by an observer blind to the experimental design.

Thioflavin S. Paraffin sections $(8 \mu \mathrm{m})$ were deparaffinized and rehydrated. Sections were stained by submerging the sections in $1 \%$ Thioflavin $\mathrm{S}(\mathrm{ThS} ; \mathrm{w} / \mathrm{v})$ for $20 \mathrm{~min}$ in the dark and then were washed in $70 \%$ ethanol for $5 \mathrm{~min}$. To measure the plaque extent load, five sections per animal were chosen randomly and imaged using the epifluorescence microscope (Eclipse 800; Nikon) equipped with a Cool Snap-FX monochrome CCD camera (Photometrics) using standard Nikon FITC and DAPI filters. Images were acquired using the Metavalue version 7.1 software (Molecular Devices). Three visual fields from the cortex and hippocampus of each section were analyzed using NIH ImageJ software by an observer blind to the experimental design.
Statistics. Data were analyzed with GraphPad Prism 5 (GraphPad Software) and Excel (Microsoft). A value of $p<0.05$ was considered significant. Error bars represent the standard error of the mean (SEM). Statistical analyses between two groups were performed by using the two-tailed Student's $t$ test, whereas comparisons involving multiple groups were performed with a two-way analysis of variance (ANOVA), followed by Bonferroni's post hoc test for multiple comparisons.

\section{Results}

\section{Age-dependent tau oligomers formation in Tg2576 mice}

The Tg2576 transgenic mouse expressing human mutant APP (K670N/M671L) (Hsiao et al., 1996) provides a model of AD-like pathology, including accumulation of $A \beta$ peptides, plaque deposition, and cognitive deficits that worsen with age (Dineley et al., 2002; Westerman et al., 2002; Hernandez et al., 2010). Additionally, there is evidence for abnormally phosphorylated tau and the presence of dystrophic neurites in this model (Noda-Saita et al., 2004).

First, we determined the existence of tau oligomers in Tg2576 mice by analyzing the PBS-soluble fraction of brain homogenates from mice at different ages by ELISA using TOMA (CastilloCarranza et al., 2014b) and Western blot probed with Tau 5 antibody. We found a significant age-dependent increase in tau oligomers with a pronounced peak at 14 months of age, followed by a reduction at month 16 (Fig. $1 A, B ;{ }^{\star *} p>0.01,{ }^{\star * \star} p>0.001$, ${ }_{* * * *} p>0.0001$, two-way ANOVA, Bonferroni's post hoc test). No evidence of tau oligomers was found in WT animals. To confirm these findings, brain paraffin sections from 14-month-old Tg2576 mice were immunostained with TOMA. Tau oligomers were found spread widely throughout the brain, including the cortex, hypothalamus, and cerebellum, as demonstrated by the strong immunoreaction to TOMA (Fig. 1C).

\section{Improved cognition in Tg2576 immunized with TOMA}

Although several examples of immunotherapeutic approaches targeting A $\beta$ in Tg2576 mice exist (Morgan et al., 2000; Kotilinek et al., 2002; Wilcock et al., 2004; Rasool et al., 2013), removal of tau using this approach has not yet been investigated. We demonstrated previously that clearance of tau oligomers in a tauopathy mouse model rescued cognitive and motor deficits without interfering with normal (monomeric) tau function (CastilloCarranza et al., 2014a,b). To address the benefit of targeting tau oligomers for cognitive and nonpathological benefit, 14-monthold Tg2576 and WT mice were injected with one dose $(30 \mu \mathrm{g})$ of TOMA, administered to the lateral vein of the tail. A control treatment group referred to as the IgG group were immunized with a single dose $(30 \mu \mathrm{g})$ of anti-Rhodamine antibody (IgG, nonspecific). Two weeks after treatment, learning and memory was evaluated using two different paradigms: NOR and FC. NOR test (cortex/hippocampus-dependent) is based on the instinctual preference of rodents to explore an NO rather than an FO. FC measures a rodent's instinctual response to fear as freezing behavior. Transgenic mice treated with TOMA exhibited improved memory as demonstrated by significant exploration of the NO, whereas the FO was explored at chance level $\left({ }^{*} p<0.05\right)$ compared with mice treated with a control antibody (IgG group), which could not distinguish between the objects (two-way ANOVA, Bonferroni's post hoc test; Fig. 1D).

We have demonstrated previously that Tg2576 mice exhibit a selective impairment in the hippocampus-dependent contextual FC test (Dineley et al., 2002; Hernandez et al., 2010). FC consists of training the mouse to associate a mild footshock with an auditory stimulus (cued FC) and a specific environment (contextual 


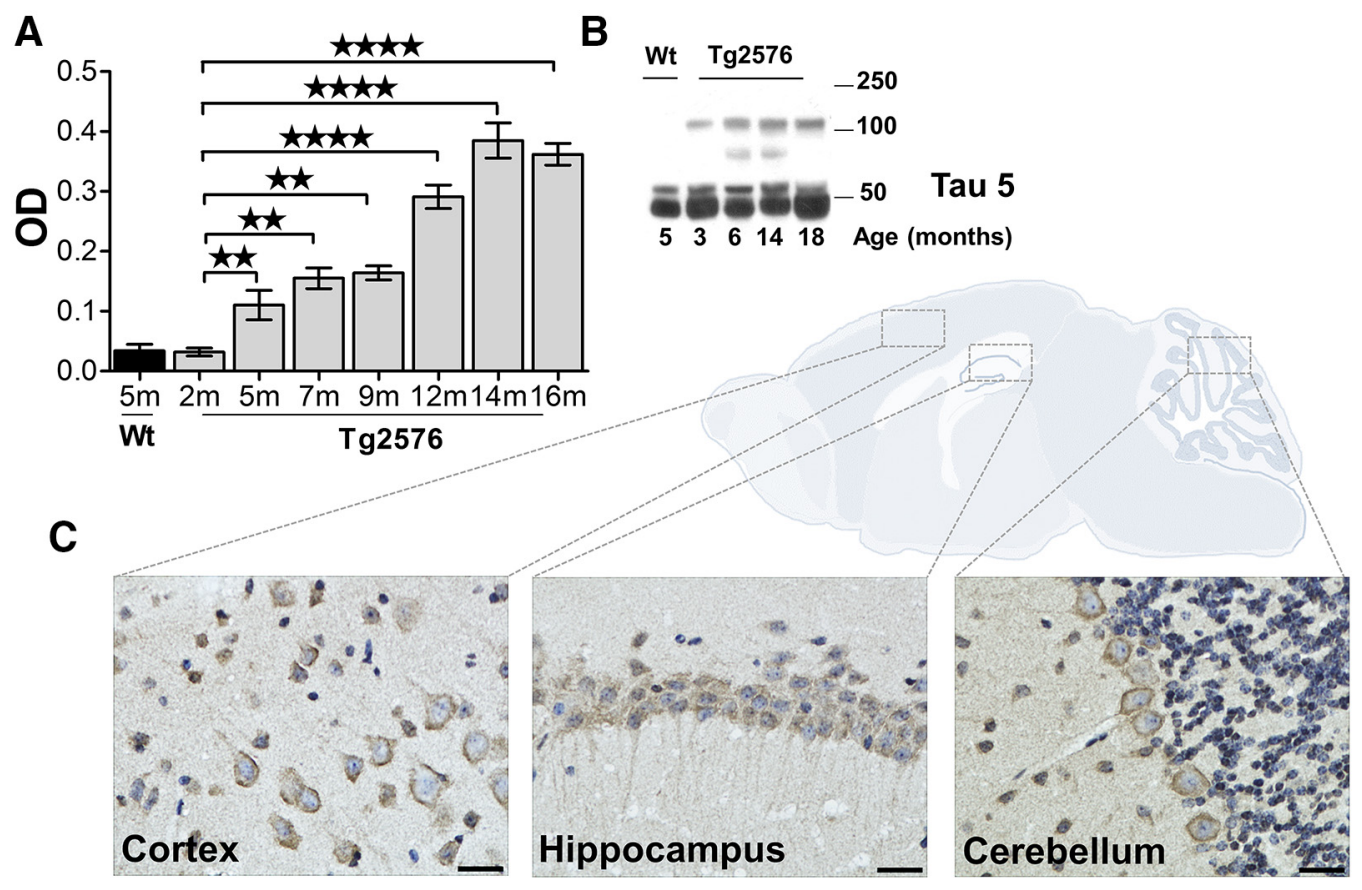

D Novel Object Recognition

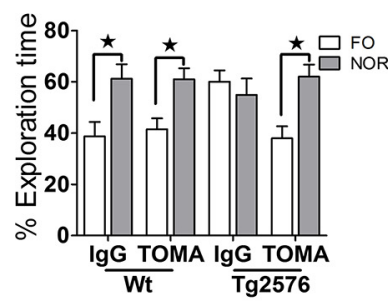

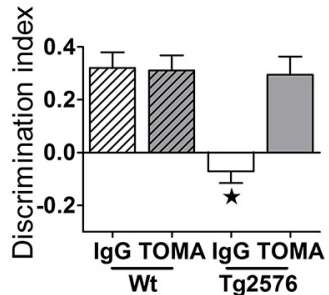
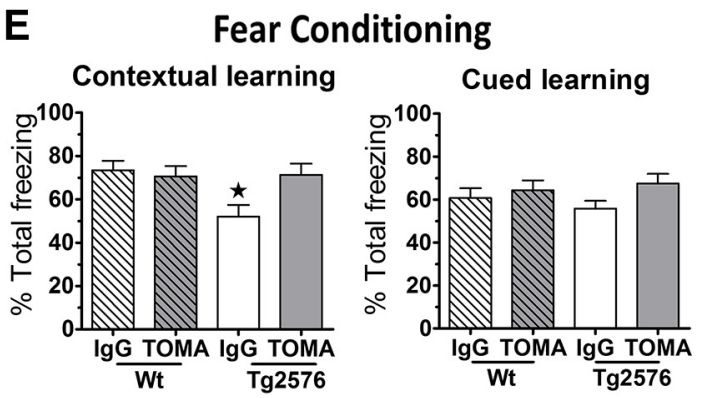

Figure 1. Removal of tau oligomers in mice immunized with TOMA rescued cognitive deficits. $A$, Quantitative analysis of tau oligomers determined in the PBS-soluble fraction of brain homogenates from Tg2576 and WT mice at different ages using TOMA and total tau using Tau 5 antibody. $\boldsymbol{A}, \boldsymbol{B}$, Tau oligomers increased in an age-depend manner with a pronounced peak at 14 months of age in Tg2576 mice ${ }^{* *} p>0.01,{ }^{* * *} p>0.001,{ }^{* * *} p>0.0001$, two-way ANOVA, Bonferroni's posthoc test). Bars represent the means and error bars the SEM. C, Immunohistochemistry analysis of paraffin sections from 14-month-old Tg2576 mouse brain, stained with TOMA and hematoxylin counterstaining. Tau oligomers were found in the cortex, hippocampus, and cerebellum, as demonstrated by immunoreactivity to TOMA (brown). Scale bar, $25 \mu \mathrm{m}$. D, E, Fourteen-month-old Tg2576 mice and WT mice ( $n=12-14$ animals per group) were injected intravenously with $30 \mu \mathrm{g}$ of control antibody (Ig group) or $30 \mu \mathrm{g}$ of TOMA. Cognition was evaluated 2 weeks after immunization. D, Comparison of time spent exploring F0 (white bar) versus N0 (gray bar). Transgenic mice receiving the control antibody (lgG group) could not differentiate between objects. Mice immunized with TOMA spend more time exploring NOR over the F0 ( ${ }^{*} p>0.05$, two-way ANOVA Bonferroni's post hoc test). Discrimination index graph represents the time spent exploring the F0 subtracted from the time spent exploring the N0 divided by the total time exploring both objects. Mice receiving the control antibody had a discrimination index of -0.2 , with no possibility to recognize the N0 as TOMA group did ( ${ }^{*} p>0.05$, two-way ANOVA, Bonferroni's post hoc test). E, The FC test was evaluated after the NOR test. Contextual FC showed that Tg2576 mice immunized with TOMA (gray bar) freeze similarly to WT mice (striped bars) than the lgG group (white bar; ${ }^{*} p>$ 0.05 , two-way ANOVA Bonferroni's post hoc test). No difference between treatments was observed in the cued learning test (two-tailed Student's $t$ test). Data reported as mean percentage total freezing time \pm SEM. No effect of treatments was seen in WT mice in any of these tests.

FC). No significant difference in freezing behavior was measured between the treatment groups during the training phase (data not shown). The contextual FC (hippocampus-dependent) test, performed $24 \mathrm{~h}$ after the acquisition phase, showed that Tg2576 mice receiving TOMA exhibited higher percentage of freezing behavior, whereas mice treated with a control antibody (IgG group) froze significantly less $\left({ }^{*} p>0.05\right.$, two-way ANOVA Bonferroni's post hoc test). The cued FC (amygdala-dependent) test was performed $6 \mathrm{~h}$ after the contextual test. Mice immunized with TOMA antibody exhibited statistically equivalent freezing behavior to the control IgG group (two-way ANOVA, Bonferroni's post hoc test; Fig. 1E). No effects of treatment were observed in WT mice.
Reduction of tau oligomers in mice immunized with TOMA coincided with memory improvement

To investigate the effects of the TOMA immunization regimen in brain tissue, we examined histologic and biochemical changes in mice treated with either TOMA or control (IgG) antibody. To evaluate the levels of tau oligomers and $\mathrm{A} \beta$ pathology, a doublelabel immunofluorescence staining technique was performed in paraffin sections from both treatment groups using T22 (Lasagna-Reeves et al., 2012a) and 4G8 antibodies (Fig. 2A-F). Mice treated with the control antibody (IgG group) showed abundant tau oligomers (stained with T22 and shown in red) in the cortex area (Fig. $2 A$ ) and a characteristic staining pattern with 4G8 (anti- $\beta$-amyloid antibody; Fig. $2 C$, green). Mice receiving 

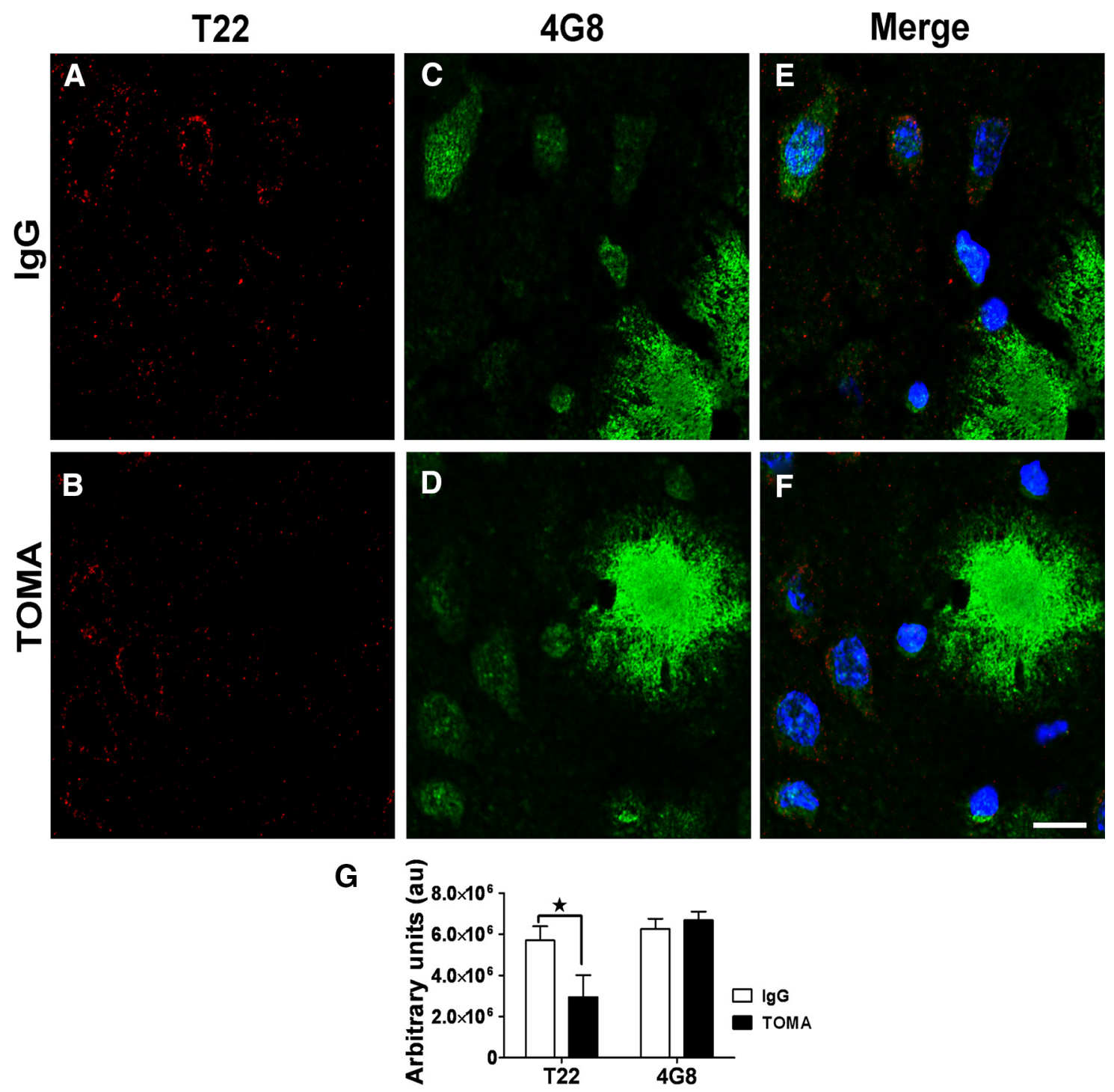

Figure 2. Reduction of tau oligomers in mice immunized with TOMA. $\boldsymbol{A}-\boldsymbol{F}$, Confocal images of brain section from mice immunized control antibody (IgG group) or TOMA, stained with T22 ( $\boldsymbol{A}, \boldsymbol{B})$ and 4G8 $(\boldsymbol{C}, \boldsymbol{D})$. Merge is shown in $\boldsymbol{E}$ and $\boldsymbol{F}$. Mice receiving the control antibody (IgG group) showed abundant tau oligomers (showed in red; $\boldsymbol{A}$ ) and a characteristic $4 \mathrm{G} 8$ immunoreaction pattern (showed in green; $\boldsymbol{C}$ ). A remarkable reduction of tau oligomer (showed in red; $\boldsymbol{B}$ ) was observed in mice immunized with TOMA. No difference was found using $4 \mathrm{G} 8$ (D). Scale bar, $25 \mu \mathrm{m}$. $\mathbf{G}$, The graph represents the pixel quantitation exhibit by T22 and 4G8.

TOMA showed an obvious reduction in the appearance of oligomeric tau staining (Fig. $2 B$ ). However, $A \beta$ levels (shown in green) did not exhibit any effect (Fig. 2D). No evidence of inflammation was observed after TOMA treatment (data not shown). Quantification by ELISA confirms the reduction of tau oligomer levels in brains of mice receiving TOMA (T22, gray bar, ${ }^{\star} p<0.02$, twotailed Student's $t$ test), whereas there was no difference between groups regarding the concentration of total Tau, measured with Tau 5 antibody (two-tailed Student's $t$ test; Fig. $3 A$ ). These findings suggest that the reduction of tau oligomer levels in the brain is important to alleviate the memory deficits described previously in Tg2576 mice.

Tau oligomer immunotherapy shifts the $\mathrm{A} \boldsymbol{\beta}$ pathway to amyloid plaques

Given that Tg2576 is a transgenic mouse model characterized by the accumulation of $\mathrm{A} \beta$ peptide, we determined the concentration of $\mathrm{A} \beta$ pathology in the PBS-soluble and -insoluble fractions of brain homogenate from mice immunized with TOMA and mice receiving a control antibody (IgG group). No difference was found between groups, as demonstrated by ELISA analyses using $4 \mathrm{G} 8$ antibody (Fig. 3A). However, A $\beta$ oligomers measured with A11 antibody decreased in the PBS-soluble fraction from mice treated with TOMA but not in those treated with the control antibody (IgG group; Fig. 3A). Confocal images from brain sections immunostained with $\mathrm{A} 11$ and $\mathrm{T} 22$ confirmed the reduction of $\mathrm{A} \beta$ oligomers in the TOMA group (Fig. $3 C-H$ ). Surprisingly, the levels of $\mathrm{A} \beta$ measured with $\mathrm{OC}$ (anti-amyloid fibrils antibody) increased in the PBS-insoluble fraction of mice treated with TOMA $\left({ }^{*} p<0.05\right)$ compared with control antibody (IgG group; two-tailed Student's $t$ test; Fig. $3 B$ ). Presumably, this fraction mainly contains large fibrillar material (Kayed et al., 2007; Sarsoza et al., 2009). Therefore, an immunohistochemical analysis was undertaken to detect amyloid plaque using the OC antibody. A marked increase of amyloid plaques (arrows) was found across the brain of mice treated with TOMA (Fig. $4 B, D, F-H$ ), whereas there was no effect in the control group (IgG group; Fig. $4 A, C, E, G, H)$. To quantify the extent of plaque load, ThS stain- 
A

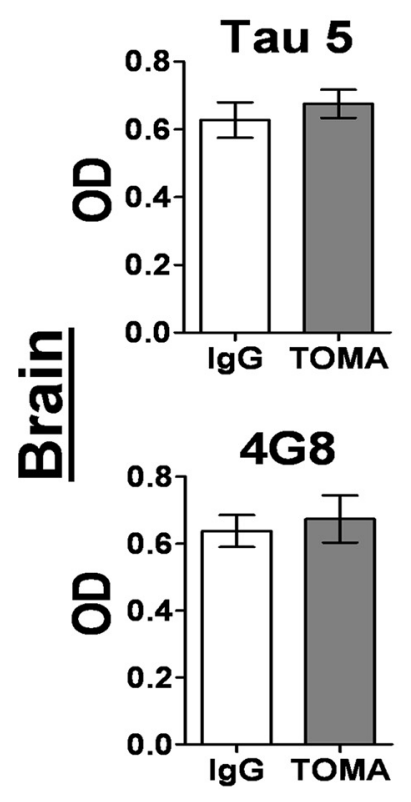

T22
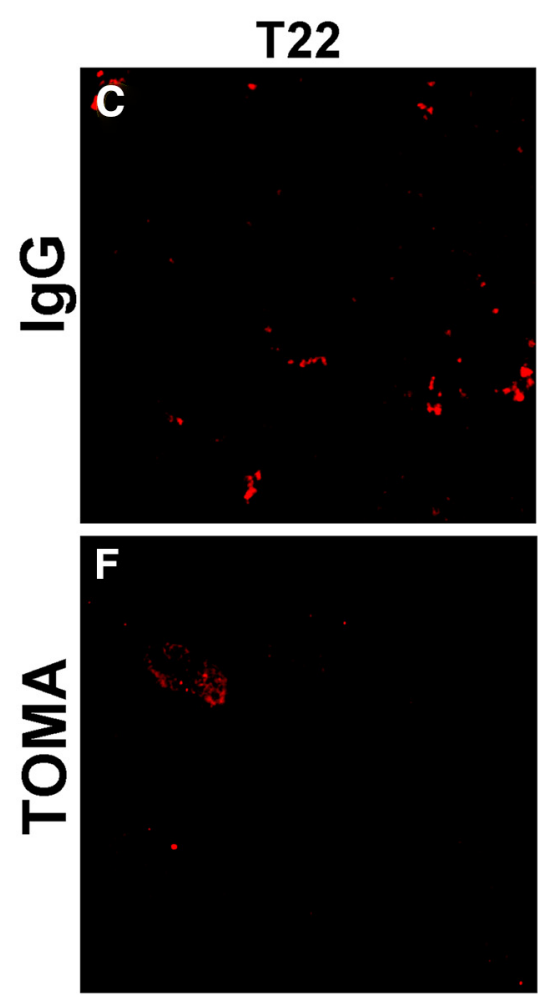

\section{PBS-soluble}
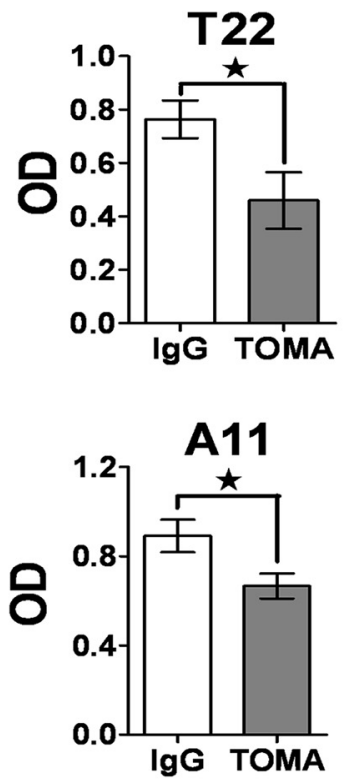

A11
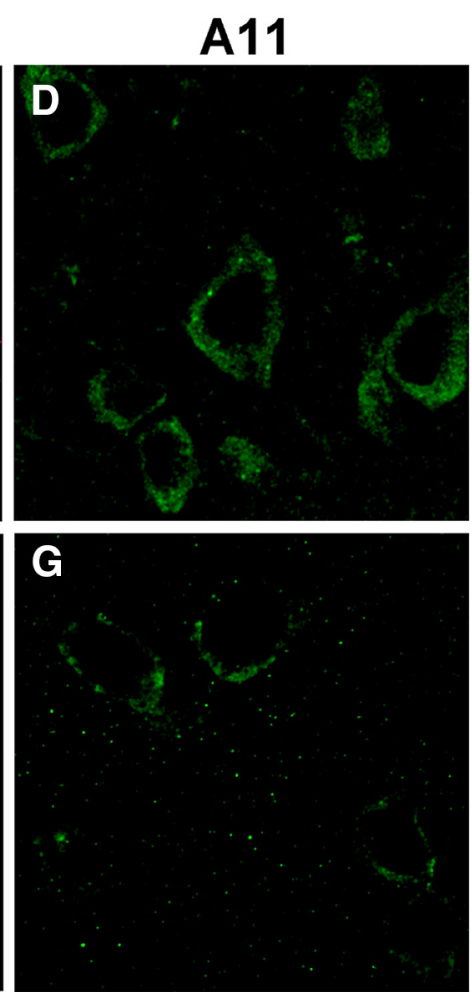

B

\section{PBS-insoluble}
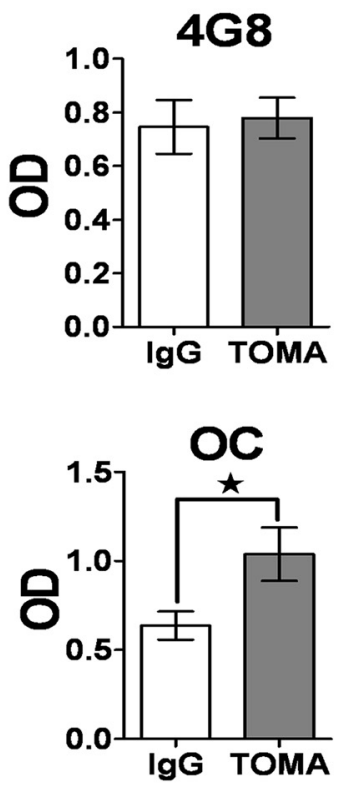

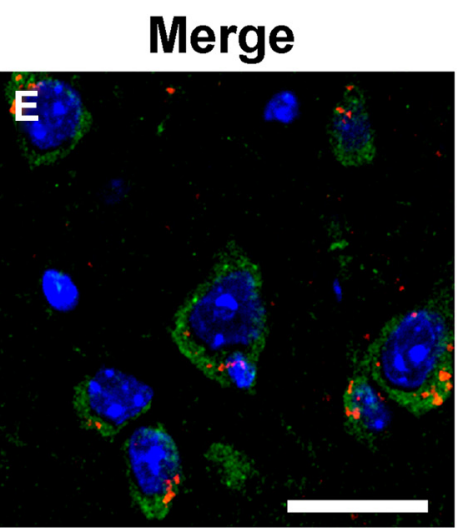

H

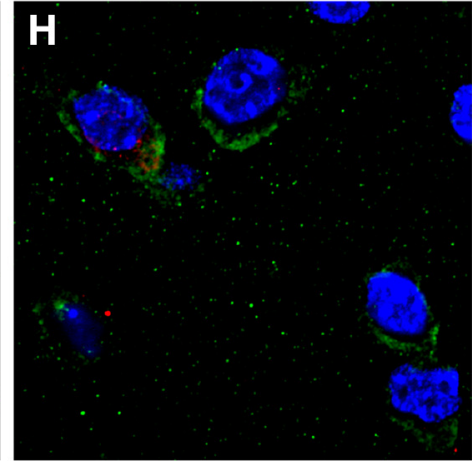

Figure 3. Removal of tau oligomers by immunotherapy decrease $A \beta$ oligomers. $A, B$, ELISA analyses of tau oligomers (T22), total tau (Tau 5), and A $\beta$ status (4G8, A11, and OC) from PBS-soluble $(\boldsymbol{A})$ and PBS-insoluble $(\boldsymbol{B})$ fractions of mice immunized with the control antibody (lgG group) and TOMA. $\boldsymbol{A}$, The TOMA group (gray bar, ${ }^{*} p>0.02$ ) displayed a reduction of tau oligomers in the soluble fraction compared with the lgG group (white bar). No effect was observed regarding Tau 5 and $4 \mathrm{G} 8$ quantitation. A $\beta$ oligomers decreased in the TOMA group (gray bar, ${ }^{*} p>0.02$ ). $\boldsymbol{B}$, Increase of $A \beta$ levels $0 C$ dependent in the PBS-insoluble fraction of the TOMA group (gray bar, ${ }^{*} p>0.05$ ) compared with the lgG group (white bar). No different between treatments was found with $4 G 8$. Data reported as $0 D$ value \pm SEM; two-tailed Student's $t$ test. $\boldsymbol{C}-\boldsymbol{H}$, Confocal images of brain sections from mice immunized with a control antibody (IgG group; $\boldsymbol{C}-\boldsymbol{E})$ or TOMA $(\boldsymbol{F}-\boldsymbol{H})$, immunostained with T22 (C, $\boldsymbol{F})$ and A11 (D, G). Scale bar, $25 \mu \mathrm{m}$.

ing was performed on brain sections from both treatment groups (Fig. $4 E, F$ ). Consistent with the levels of $\mathrm{A} \beta$ found in the PBSinsoluble fraction, ThS-positive plaques increased in the cortex (Fig. $3 G$, white bar; ${ }^{\star} p<0.04$, two-tailed Student's $t$ test) and hippocampus (Fig. $4 H$, white bar; ${ }^{\star} p<0.03$ ) of mice treated with TOMA compared with the control IgG group (black bar; twotailed Student's $t$ test). Overall, the data suggest that a decrease in tau oligomers in the brain shifts the $A \beta$ aggregation pathway to 

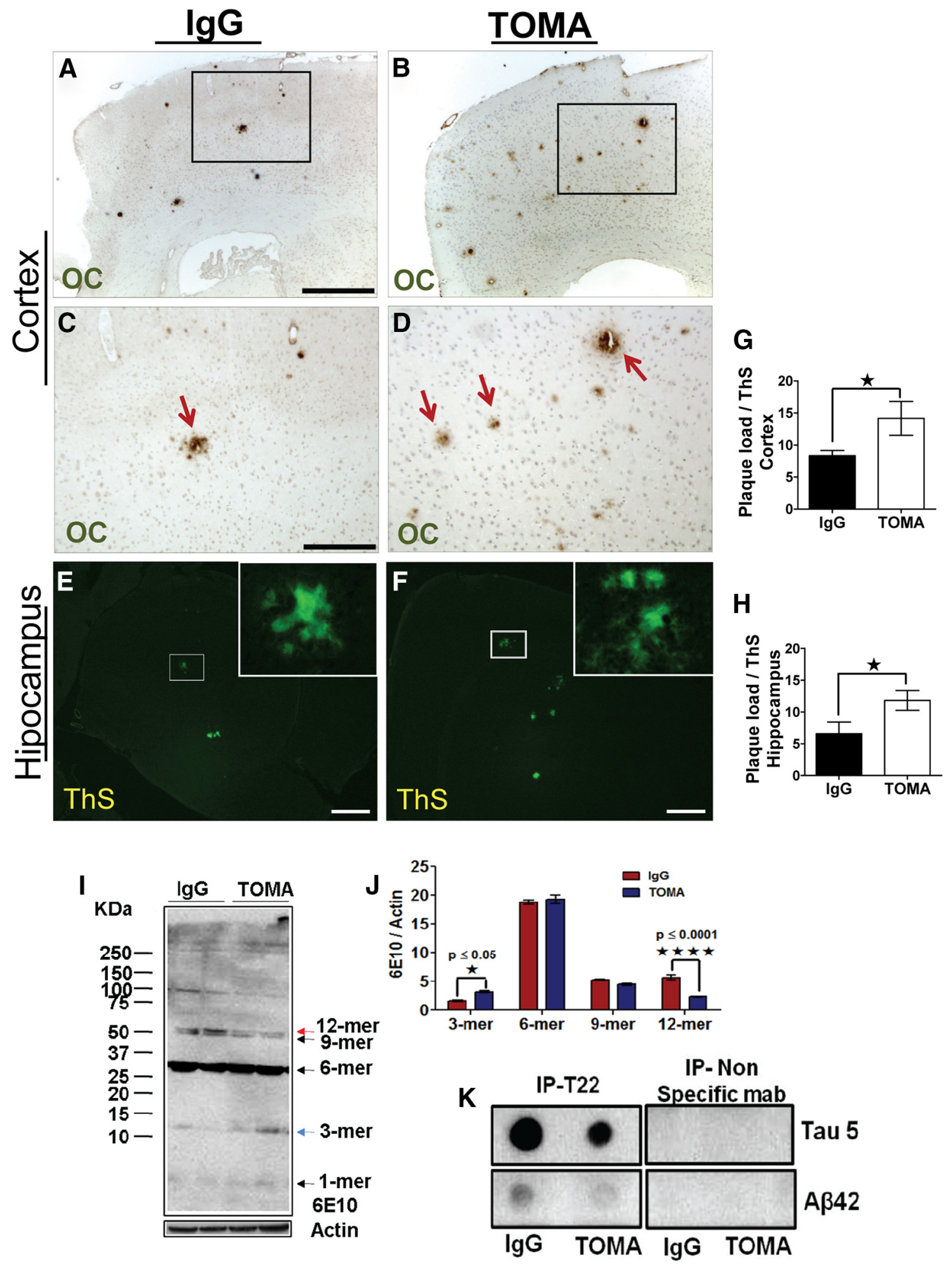

Figure 4. Tau oligomer immunotherapy shifts the $A \beta$ aggregation pathway to amyloid plaques. $\boldsymbol{A}-\boldsymbol{D}$, Immunohistochemistry analysis of brain sections from $14-\mathrm{month}-0 \mathrm{ld}$ Tg2576 mice treated with TOMA and control antibody (IgG group) using $O C$ antibody. $A, C$, Characteristic pattern of plaque staining displayed in the lgG group. $\boldsymbol{B}, \boldsymbol{D}$, Mice immunized with TOMA revealed a striking increase of amyloid plaques (arrows) in the cortex. $\boldsymbol{C}$ and $\boldsymbol{D}$ are an enlargement of the boxed area showed in $\boldsymbol{A}$ and $\boldsymbol{B}$. ThS staining from brain sections of mice immunized with the control antibody (IgG group) and TOMA $(\boldsymbol{E}, \boldsymbol{F})$. ThS-positive plaques increased in the cortex (G; white bar; $\left.{ }^{*} p<0.04\right)$ and hippocampus $\left(\boldsymbol{H} ;\right.$ white bar; ${ }^{*} p<0.03$ ) of mice treated with TOMA compared with the IgG group (black bar; two-tailed Student's $t$ test). The graphs represent the average of the number of plaques per field. $I$, Representative Western blot analysis of PBS-soluble fraction of brain homogenate from mice immunized with control antibody (IgG group) or TOMA probed with 6E10 antibody. Mice treated with TOMA showed a decrease of $A \beta$ dodecamer ( $A \beta^{*} 56$; red arrow) and an increase of trimers (blue arrow) compared with the lgG group. J, The band density relative to $6 \mathrm{E} 10$ was normalized with actin and plotted. The band density of $A \beta$ trimers and dodecamer were statistically different between treatment groups $\left({ }^{*} p<0.05,{ }^{* * * *} p<0.0001\right.$, two-way ANOVA, Bonferroni's post hoc test). $\boldsymbol{K}$, Dot blot analysis of tau oligomers immunoprecipitated from the lgG or TOMA groups using T22 or control antibody, probed with Tau 5 and $A \beta_{1-42}$ antibody. 
amyloid plaques, which seem to be inert (Jankowsky et al., 2003, 2005; Fowler et al., 2014).

\section{Removal of tau oligomers by immunotherapy influences A $\beta^{\star} 56$ levels}

In the $T g 2576$ mice, a dodecamer $A \beta$ aggregate $\left(A \beta^{\star} 56\right)$ seems to be responsible for memory impairment (Lesné et al., 2006). Therefore, we evaluated TOMA effects on $\mathrm{A} \beta$ pathology by Western blot (Fig. 4I). Densitometry analysis of antibody 6E10 revealed a reduction of $\mathrm{AB}^{\star} 56$ (red arrow) and an increase of $\mathrm{A} \beta$ trimers (blue arrow) in the PBS-soluble fraction of mice immunized with TOMA compared with control IgG-treated mice (blue bar; two-way ANOVA, ${ }^{*} p>0.05,{ }^{* * *} p>0.0001 ;$ Fig. $\left.4 J\right)$. These findings suggest that removal of tau oligomers directly affects $\mathrm{A} \beta$ aggregation, highlighting a possible interaction between them, perhaps in promoting pathology. Moreover, the effect of TOMA treatment on $\mathrm{A} \beta$ pathology cannot be attributed to antibody nonspecificity, because we demonstrated previously that TOMA does not recognize $\mathrm{A} \beta$ or other amyloidogenic proteins (CastilloCarranza et al., 2014a,b).

To test the hypothesis that $\mathrm{A} \beta$ and tau could be interacting directly, tau oligomers were IP using T22 antibody from brain extracts of mice immunized with TOMA and mice receiving the control antibody (IgG group). A nonspecific antibody (antiRhodamine antibody) was used as a negative control. Dot blot analysis of IP tau oligomers probed with Tau 5 and anti- $\mathrm{A} \beta_{42}$ antibody confirmed that mice immunized with TOMA displayed lower levels of tau and $\mathrm{A} \beta$, in contrast to the high levels found in mice receiving the control antibody. The IP assay using a nonspecific antibody did not exhibit an immunoreaction with Tau 5 or anti- $\mathrm{A} \beta_{42}$ antibody. Together, these findings suggest that tau oligomers could be interacting with $A \beta_{1-42}$ in the brain of 14month-old Tg2576 mice (Fig. 4K).

\section{TOMA immunization increases mushroom spines in Tg2576 mice}

Previous studies suggest that abnormal morphology of neuronal dendritic spines affect memory and learning processes (Coleman and Yao, 2003). A reduced number of spines and abnormal morphology have been described previously in Tg2576 mice (Spires et al., 2005; Jacobsen et al., 2006). Therefore, we investigated whether or not cognitive improvement observed after treatment with TOMA is associated with any changes in spine morphology in the vicinity of amyloid plaques. Golgi staining followed by immunostaining with $\mathrm{OC}$ was used to visualize neuronal dendritic spines and amyloid plaques from brain sections of mice receiving a control antibody (IgG group) and mice treated with TOMA (Fig. $5 A-C$ ). Our analysis of spine density at distances of less than or more than $15 \mu \mathrm{m}$ from the plaque edge did not show any statistical differences between the two treatment groups (two-way ANOVA, Bonferroni's post hoc test; Fig. 5B). A morphometric analysis of dendritic spines categorized as mushroom, stubby, or thin in appearance revealed that mice receiving a control antibody (IgG group) had a predominant number of thin spines over those with a mushroom or stubby shape, whereas mice immunized with TOMA displayed an increase of spines with mushroom shape $\left({ }^{*} p>0.05,{ }^{* *} p>0.01\right.$, two-way ANOVA, Bonferroni's post hoc test; Fig. $5 C$ ). These findings suggest that mice treated with TOMA could influence the morphology of dendritic spines, independently of proximity to plaques.

We next analyzed the status of tau aggregates in brain homogenates from mice immunized with TOMA or control antibody by Western blot using the pan anti-tau antibody Tau 5. A marked and specific reduction of tau oligomers $(\sim 64-150 \mathrm{kDa})$ was found in only the TOMA group (Fig. $5 D$ ). Tau protein is known to interact with Fyn, a protein that is important in axonal growth and guidance at synapses. Therefore, we analyzed Fyn in brain homogenates from mice treated with control antibody (IgG group) or TOMA by Western blot. Densitometric analysis of Fyn did not detect any difference between the treatment groups, suggesting that another mechanism is likely involved (Fig. 5D,F). Examination of GSK3 $\beta$, which is well known to phosphorylate tau protein at multiple sites, using GSK3 $\beta$ (Y279/Y216) antibody on the same blot, showed decreased GSK3 $\beta$ activity in mice receiving TOMA compared with mice administered with the control antibody (IgG group; Fig. 5D, G).

\section{Discussion}

An unsolved question in $\mathrm{AD}$ progression is the mechanistic relationship between $A \beta$ and tau pathology. Accumulating evidence suggest that the detrimental effects of $\mathrm{A} \beta$ are dependent on tau pathology (Roberson et al., 2007; Desikan et al., 2011; Nussbaum et al., 2012; Bloom, 2014), signifying that removal of pathological forms of tau may confer benefits for AD. Recently, preclinical studies have shed some light on the use of tau pathology as an immunotherapeutic target; however, these studies have, for the most part, been directed at specific phosphorylated tau epitopes (Boimel et al., 2010; Boutajangout et al., 2010; Bi et al., 2011; Chai et al., 2011; Troquier et al., 2012; Rozenstein-Tsalkovich et al., 2013; Theunis et al., 2013; Yanamandra et al., 2013; d'Abramo et al., 2013; Walls et al., 2014). Recently, we demonstrated that reduction of tau oligomers through passive immunization reversed cognitive and motor deficits associated with tau pathology in mice (Castillo-Carranza et al., 2014a,b). Here, we extended our studies to examine the mechanistic effects of removal of tau oligomers via immunotherapy in an $\mathrm{AD}$ mouse model.

We found that tau oligomers increase in an age-dependent manner in Tg2576 brain regions associated with memory, including the hippocampus and cortex, indicating that tau oligomers contribute to the disruption of memory function. This suggested to us the possibility that removal of tau oligomers may be an important strategy to prevent the full potential of the harmful effects of A $\beta$ and tau (Kayed, 2010; Lasagna-Reeves et al., 2011a; Castillo-Carranza et al., 2013a,b).

Significantly, we showed that a single intravenous dose of TOMA reduces tau oligomers from the brains of Tg2576 mice and ameliorated memory deficits in a cortex- and hippocampusdependent manner, implying a role of tau in mediating cognitive decline. Nevertheless, $A \beta$ dodecamer assembly, referred to as $\mathrm{A} \beta^{\star} 56$, has been long considered the major factor in memory deficits in several mouse models, including Tg2576 (Kim et al., 2006; Lesné et al., 2006; Cheng et al., 2007). This apparent discrepancy suggests that tau can either impair cognition directly (Santacruz et al., 2005) or via A $\beta$. Given that Oddo et al. (2006) showed that reduction of $\mathrm{A} \beta$ alone by immunotherapeutic approaches was not sufficient to improve cognition in mice displaying tau pathology but reduction of both pathologies did confer benefits suggests a more intercalated relationship and that tau may serve a dominant role in cognitive decline.

Using the Tg2576 mouse model, we found that removal of tau oligomers by TOMA immunotherapy shifted the $\mathrm{A} \beta$ aggregation pathway to amyloid plaques, the less toxic aggregate and perhaps a protective entity. Our findings are consistent with previous work suggesting that an increase of plaques is not associated with neurological deficits (Cheng et al., 2007) but rather beneficial 
A
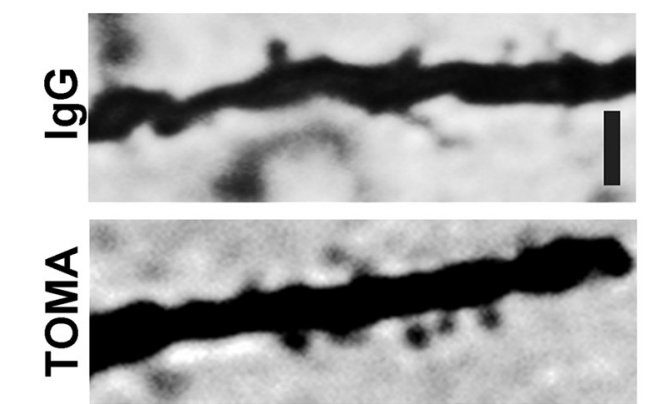

B

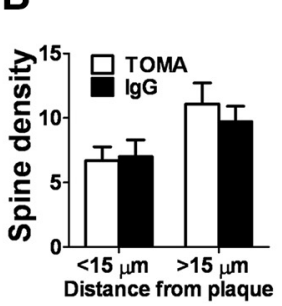

C

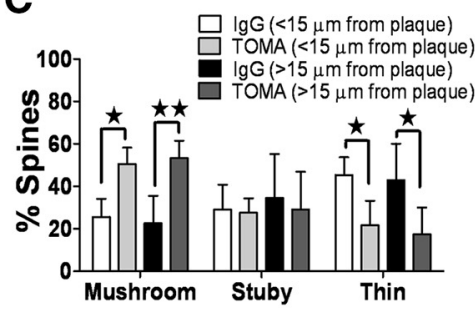

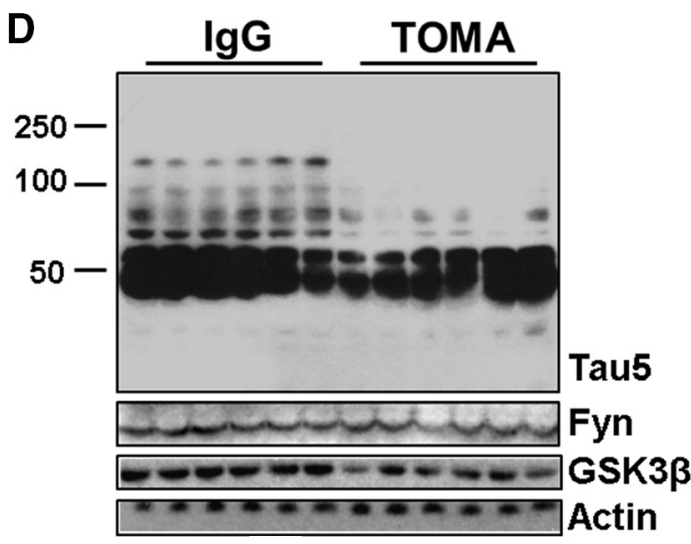

E
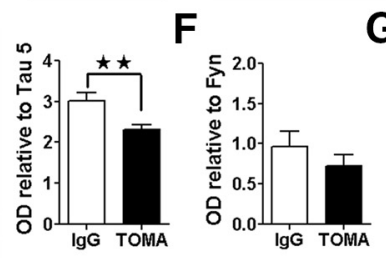

G

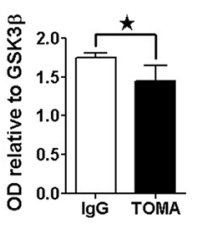

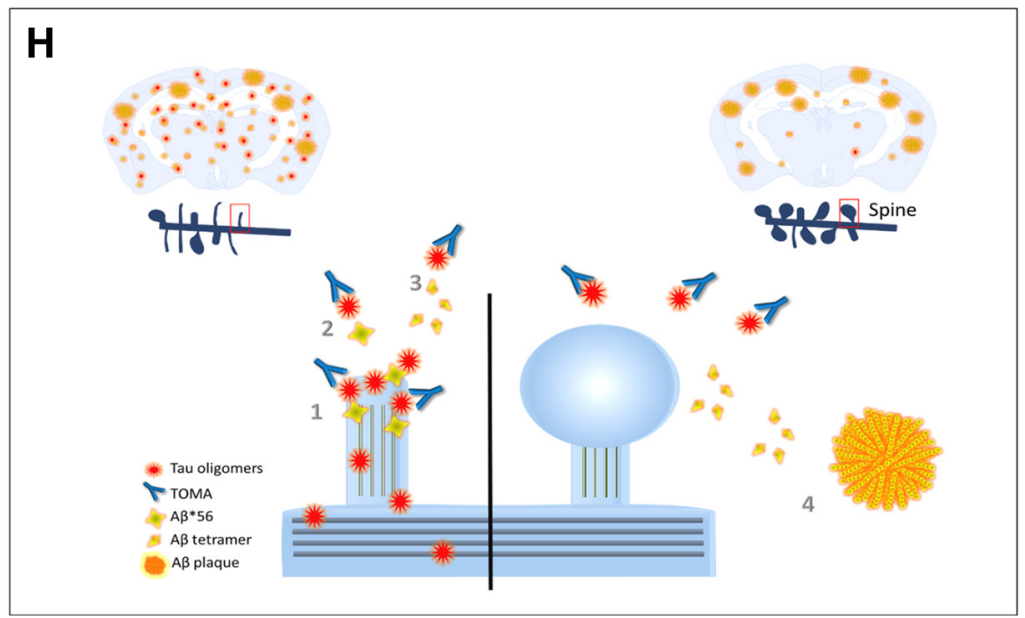

Figure 5. TOMA immunization increases mushroom spines in Tg2576. A, Representative image of dendrite segment displaying spine morphology from 14 -month-old Tg2576 mice immunized with a control antibody (lgG group) and TOMA, stained using the Golgi method. Scale bar, $2 \mu \mathrm{m}$. B, Quantitative analysis of spine density at $<15 \mu \mathrm{m}$ or $>15 \mu \mathrm{m}$ of plaque edge did not exhibit a difference between treatment groups (two-way ANOVA, Bonferroni's post hoc test). C, Analysis of spine morphology indicates that mice immunized with TOMA increased mushroom-shaped spines compared with the $\lg \operatorname{group}\left({ }^{*} p>0.05,{ }^{* *} p>0.01\right.$, two-way ANOVA, Bonferroni's post hoc test). D, Western blot analysis of the PBS-soluble fraction from brain homogenates of mice immunized with control antibody (lgG group) or TOMA probed with Tau 5, Fyn, GSK3 $\beta$, and actin antibodies. E, Mice treated with TOMA showed an evident reduction of tau aggregates reactive to Tau 5 $\left(\sim 64-150 \mathrm{kDa}\right.$; black bar; $\left.{ }^{* *} p>0.008\right)$. $\boldsymbol{F}$, No difference between treatments groups was observed on Fyn immunoreaction. $\mathbf{G}$, Mice immunized with TOMA exhibit a reduction of GSK3 $\beta$ (Y279/Y216) compared with the lgG group (black bar; ${ }^{*} p>0.016$ ). The actin is shown at the bottom. Data reported as OD value \pm SEM; two-tailed Student's $t$ test. $\boldsymbol{H}$, Schematic representation of the possible effects of TOMA in dendritic spines of Tg2576 mice brain. 1, TOMA recognize tau oligomers. 2, TOMA traps tau oligomers linked to A $\beta^{*} 56.3$, A $\beta^{*} 56$ is disassembled into trimers. 4, Trimeric $A \beta$ aggregate into amyloid plaques, increasing the plaque load in mice brain.

effects because cognitive functions were improved in mice (Jankowsky et al., 2003, 2005; Lesné et al., 2008).

Biochemical analysis of mice treated with TOMA revealed a marked reduction of $\mathrm{A} \beta^{\star} 56$ and an increase of trimers, suggesting that removal of tau oligomers influenced $\mathrm{A} \beta$ levels. Previous studies have proposed that $\mathrm{A} \beta \beta^{\star} 56$ is a buildup with four $\mathrm{A} \beta$ trimers (Lesné et al., 2006); therefore, the increase of trimers in mice treated with TOMA may be a consequence of A $\beta^{\star} 56$ disassembly. Importantly, this increase was surmised to not cause impairment in mice, because administration of trimers in rats does not disrupt cognition (Reed et al., 2011). In humans, $A \beta$ dimers and trimers have been found in neurological intact individuals, whereas $\mathrm{A} \beta^{\star} 56$ seems to have a pathogenic role in the asymptom- atic phase of AD. Notably, $A \beta^{\star} 56$ correlates with the pathological form of tau but not with dimers or trimers (Lesné, 2013). In CSF, $\mathrm{A} \beta$ trimers and $\mathrm{A} \beta^{\star} 56$ correlate with tau pathology in individuals at risk for $\mathrm{AD}$ (Handoko et al., 2013). However, although $\mathrm{A} \beta$ dimers do not seem to influence cognition in Tg2576 mice, isolation of dimers from human samples impairs synaptic plasticity and memory in healthy rats (Shankar et al., 2008). Significantly, recent work has shown that $\mathrm{A} \beta$ dimers isolated from $\mathrm{AD}$ samples trigger endogenous tau hyperphosphorylation, followed by neuritic degeneration of cells in culture (Jin et al., 2011).

Based on our studies reported here, we hypothesize an interaction between tau oligomers and $A \beta$ in the Tg2576 mouse model. Our analysis of tau oligomers immunoprecipitated from 
brain extracts of mice immunized with TOMA and mice treated with a control antibody revealed that $\mathrm{A} \beta$ peptide is contained in both treatment groups. To our surprise, dot blot analysis of the coimmunoprecipitation revealed that mice treated with TOMA exhibited low levels of both tau oligomers and $A \beta$ peptide, confirming our previous results shown early here by ELISA. Thus, these findings provide evidence of an interaction between $A \beta$ and tau.

Previous observations have shown co-occurrence between tau and $\mathrm{A} \beta$ within neuronal processes and synaptic compartments (Hoover et al., 2010; Ittner et al., 2010; Zempel et al., 2010; Miller et al., 2014). Of note, different $A \beta$ assemblies, including $A \beta^{\star} 56$, are prominent in the synaptic terminals of $\mathrm{AD}$ patients (Sokolow et al., 2012). Seemingly, A $\beta$ binds preferentially to neuronal dendrites, promoting tau missorting from axon to cell body and dendrites (Zempel and Mandelkow, 2012). Moreover, this redistribution of tau seems to be responsible for spine loss (Zempel et al., 2010). Synaptic communication occurs at dendritic spines, thereby reductions of spine number or morphology changes would be expected to contribute to synaptic dysfunction and cognitive deficits. As observed in the ArcTau mouse model, the reduction of $A \beta$ oligomers resulted in decreased tau postsynaptic mislocalization and rescued cognition in those animals (Chabrier et al., 2012).

The synaptic abnormalities that are a main event in $\mathrm{AD}$ pathology have also been described in Tg2576 mice (Spires-Jones et al., 2007). Although we did not find a difference in the number of spines between treatment groups, we found a significant increase of mushroom-shaped spines after the removal of tau oligomers with TOMA. Our findings are consistent with previous observations from aged htau mice in which increased levels of tau correlate with a reduced number of mushroom-shaped spines, increases of thin spines, and cognitive deficits in aged mice. Notably, mushroom spines are considered more stable memory spines because they have large postsynaptic densities (Dickstein et al., 2010).

Remarkably, tau seems to have a crucial function at dendrites by targeting the kinase Fyn to postsynaptic compartments, resulting in the overactivation of NMDA receptors, thereby conferring neurons more susceptible to $A \beta$ cytotoxicity (Ittner et al., 2010). Fyn belongs to the Src-family kinase implicated in synapse development and plasticity (Grant et al., 1992). In APP mice, reduction of Fyn prevents $\mathrm{A} \beta$-mediated toxicity (Chin et al., 2004, 2005). However, in our immunization regimen, we did not observe any change of spine density or levels of Fyn after reduction of tau oligomers and $A \beta^{\star} 56$, suggesting that another pathway could be involved. Thus, our findings support previous observations showing that only dimeric and trimeric $\mathrm{A} \beta$, but not $\mathrm{A} \beta \beta^{\star} 56$ or protofibrils, isolated from $\mathrm{AD}$ brains activate Fyn after binding the cellular prion protein $\operatorname{PrP}^{\mathrm{c}}$ (Larson et al., 2012). Furthermore, we found that the reduction of tau oligomers by immunotherapy induces a decrease in GSK3 $\beta$ activity. Previous reports have demonstrated that GSK3 $\beta$ activation is mediated by $\mathrm{A} \beta$ (DaRocha-Souto et al., 2012). Hence, our findings suggest that reduction of tau oligomers decreases $\mathrm{A} \beta \beta^{\star} 56$, which may promote a reduction on GSK $3 \beta$ activity. This supports the hypothesis that tau enhances $A \beta$ toxicity through a feedback loop mechanism (Bloom, 2014).

In summary, our findings from TOMA immunotherapy in the Tg2576 mice indicate a link between tau oligomers and $\mathrm{A} \beta \beta^{\star} 56$. Therefore, the removal of tau oligomers with TOMA may destabilize this $\mathrm{A} \beta$ assembly, which can be then disaggregate into trimeric structures. This, in turn, may lower $\mathrm{A} \beta{ }^{\star} 56$ toxicity at the synapse and mitigate cognitive deficits. Although it is not clear how tau oligomers and $A \beta^{\star} 56$ interact, they seem to promote cognitive decline. Overall, these findings provide a mechanistic insight regarding tau oligomers and $\mathrm{A} \beta$ interaction. Our findings provide strong evidence of the benefits to targeting oligomeric tau by immunotherapeutic approaches.

\section{References}

Ashe KH (2006) Molecular basis of memory loss in the Tg2576 mouse model of Alzheimer's disease. J Alzheimer Dis 9:123-126.

Bi M, Ittner A, Ke YD, Götz J, Ittner LM (2011) Tau-targeted immunization impedes progression of neurofibrillary histopathology in aged P301L tau transgenic mice. PLoS One 6:e26860. CrossRef Medline

Bloom GS (2014) Amyloid-beta and tau: the trigger and bullet in Alzheimer disease pathogenesis. JAMA Neurol 71:505-508. CrossRef Medline

Boimel M, Grigoriadis N, Lourbopoulos A, Haber E, Abramsky O, Rosenmann H (2010) Efficacy and safety of immunization with phosphorylated tau against neurofibrillary tangles in mice. Exp Neurol 224:472-485. CrossRef Medline

Boutajangout A, Quartermain D, Sigurdsson EM (2010) Immunotherapy targeting pathological tau prevents cognitive decline in a new tangle mouse model. J Neurosci 30:16559-16566. CrossRef Medline

Busciglio J, Lorenzo A, Yeh J, Yankner BA (1995) beta-amyloid fibrils induce tau phosphorylation and loss of microtubule binding. Neuron 14: 879-888. CrossRef Medline

Castillo-Carranza DL, Lasagna-Reeves CA, Kayed R (2013a) Tau aggregates as immunotherapeutic targets. Front Biosci (Schol Ed) 5:426-438. Medline

Castillo-Carranza DL, Guerrero-Muñoz MJ, Kayed R (2013b) Immunotherapy for the treatment of Alzheimer's disease: amyloid- $\beta$ or tau, which is the right target? Immunotargets Ther 2014:3 19-28.

Castillo-Carranza DL, Gerson JE, Sengupta U, Guerrero-Muñoz MJ, Lasagna-Reeves CA, Kayed R (2014a) Specific targeting of tau oligomers in htau mice prevents cognitive impairment and tau toxicity following injection with brain-derived tau oligomeric seeds. J Alzheimers Dis 40: S97-S111. CrossRef Medline

Castillo-Carranza DL, Sengupta U, Guerrero-Muñoz MJ, Lasagna-Reeves CA, Gerson JE, Singh G, Estes DM, Barrett AD, Dineley KT, Jackson GR, Kayed R (2014b) Passive immunization with tau oligomer monoclonal antibody reverses tauopathy phenotypes without affecting hyperphosphorylated neurofibrillary tangles. J Neurosci 34:4260-4272. CrossRef Medline

Chabrier MA, Blurton-Jones M, Agazaryan AA, Nerhus JL, Martinez-Coria H, LaFerla FM (2012) Soluble abeta promotes wild-type tau pathology in vivo. J Neurosci 32:17345-17350. CrossRef Medline

Chai X, Wu S, Murray TK, Kinley R, Cella CV, Sims H, Buckner N, Hanmer J, Davies P, O’Neill MJ, Hutton ML, Citron M (2011) Passive immunization with anti-Tau antibodies in two transgenic models: reduction of Tau pathology and delay of disease progression. J Biol Chem 286:3445734467. CrossRef Medline

Cheng IH, Scearce-Levie K, Legleiter J, Palop JJ, Gerstein H, Bien-Ly N, Puoliväli J, Lesné S, Ashe KH, Muchowski PJ, Mucke L (2007) Accelerating amyloid-beta fibrillization reduces oligomer levels and functional deficits in Alzheimer disease mouse models. J Biol Chem 282:2381823828. CrossRef Medline

Chin J, Palop JJ, Yu GQ, Kojima N, Masliah E, Mucke L (2004) Fyn kinase modulates synaptotoxicity, but not aberrant sprouting, in human amyloid precursor protein transgenic mice. J Neurosci 24:4692-4697. CrossRef Medline

Chin J, Palop JJ, Puoliväli J, Massaro C, Bien-Ly N, Gerstein H, Scearce-Levie K, Masliah E, Mucke L (2005) Fyn kinase induces synaptic and cognitive impairments in a transgenic mouse model of Alzheimer's disease. J Neurosci 25:9694-9703. CrossRef Medline

Coleman PD, Yao PJ (2003) Synaptic slaughter in Alzheimer's disease. Neurobiol Aging 24:1023-1027. CrossRef Medline

d'Abramo C, Acker CM, Jimenez HT, Davies P (2013) Tau passive immunotherapy in mutant P301L mice: antibody affinity versus specificity. PLoS One 8:e62402. CrossRef Medline

DaRocha-Souto B, Coma M, Pérez-Nievas BG, Scotton TC, Siao M, SánchezFerrer P, Hashimoto T, Fan Z, Hudry E, Barroeta I, Serenó L, Rodríguez M, Sánchez MB, Hyman BT, Gómez-Isla T (2012) Activation of glyco- 
gen synthase kinase- 3 beta mediates beta-amyloid induced neuritic damage in Alzheimer's disease. Neurobiol Dis 45:425-437. CrossRef Medline

De Felice FG, Wu D, Lambert MP, Fernandez SJ, Velasco PT, Lacor PN, Bigio EH, Jerecic J, Acton PJ, Shughrue PJ, Chen-Dodson E, Kinney GG, Klein WL (2008) Alzheimer's disease-type neuronal tau hyperphosphorylation induced by A beta oligomers. Neurobiol Aging 29:1334-1347. CrossRef Medline

Desikan RS, McEvoy LK, Thompson WK, Holland D, Roddey JC, Blennow K, Aisen PS, Brewer JB, Hyman BT, Dale AM, Alzheimer's Disease Neuroimaging I (2011) Amyloid-beta associated volume loss occurs only in the presence of phospho-tau. Ann Neurol 70:657-661. CrossRef Medline

Dickstein DL, Brautigam H, Stockton SD Jr, Schmeidler J, Hof PR (2010) Changes in dendritic complexity and spine morphology in transgenic mice expressing human wild-type tau. Brain Struct Funct 214:161-179. CrossRef Medline

Dineley KT, Xia X, Bui D, Sweatt JD, Zheng H (2002) Accelerated plaque accumulation, associative learning deficits, and up-regulation of alpha 7 nicotinic receptor protein in transgenic mice co-expressing mutant human presenilin 1 and amyloid precursor proteins. J Biol Chem 277: 22768-22780. CrossRef Medline

Ferrari A, Hoerndli F, Baechi T, Nitsch RM, Götz J (2003) beta-Amyloid induces paired helical filament-like tau filaments in tissue culture. J Biol Chem 278:40162-40168. CrossRef Medline

Fowler SW, Chiang AC, Savjani RR, Larson ME, Sherman MA, Schuler DR, Cirrito JR, Lesné SE, Jankowsky JL (2014) Genetic modulation of soluble abeta rescues cognitive and synaptic impairment in a mouse model of Alzheimer's disease. J Neurosci 34:7871-7885. CrossRef Medline

Glabe CG, Kayed R (2006) Common structure and toxic function of amyloid oligomers implies a common mechanism of pathogenesis. Neurology 66:S74-S78. CrossRef Medline

Götz J, Chen F, van Dorpe J, Nitsch RM (2001) Formation of neurofibrillary tangles in P301l tau transgenic mice induced by Abeta 42 fibrils. Science 293:1491-1495. CrossRef Medline

Grant SG, O’Dell TJ, Karl KA, Stein PL, Soriano P, Kandel ER (1992) Impaired long-term potentiation, spatial learning, and hippocampal development in fyn mutant mice. Science 258:1903-1910. CrossRef Medline

Haass C, Selkoe DJ (2007) Soluble protein oligomers in neurodegeneration: lessons from the Alzheimer's amyloid beta-peptide. Nat Rev Mol Cell Biol 8:101-112. CrossRef Medline

Handoko M, Grant M, Kuskowski M, Zahs KR, Wallin A, Blennow K, Ashe $\mathrm{KH}$ (2013) Correlation of specific amyloid-beta oligomers with tau in cerebrospinal fluid from cognitively normal older adults. JAMA Neurol 70:594-599. CrossRef Medline

Hernandez CM, Kayed R, Zheng H, Sweatt JD, Dineley KT (2010) Loss of alpha7 nicotinic receptors enhances beta-amyloid oligomer accumulation, exacerbating early-stage cognitive decline and septohippocampal pathology in a mouse model of Alzheimer's disease. J Neurosci 30:24422453. CrossRef Medline

Hoover BR, Reed MN, Su J, Penrod RD, Kotilinek LA, Grant MK, Pitstick R, Carlson GA, Lanier LM, Yuan LL, Ashe KH, Liao D (2010) Tau mislocalization to dendritic spines mediates synaptic dysfunction independently of neurodegeneration. Neuron 68:1067-1081. CrossRef Medline

Hsiao K, Chapman P, Nilsen S, Eckman C, Harigaya Y, Younkin S, Yang F, Cole G (1996) Correlative memory deficits, Abeta elevation, and amyloid plaques in transgenic mice. Science 274:99-102. CrossRef Medline

Ittner LM, Ke YD, Delerue F, Bi M, Gladbach A, van Eersel J, Wölfing H, Chieng BC, Christie MJ, Napier IA, Eckert A, Staufenbiel M, Hardeman E, Götz J (2010) Dendritic function of tau mediates amyloid-beta toxicity in Alzheimer's disease mouse models. Cell 142:387-397. CrossRef Medline

Jacobsen JS, Wu CC, Redwine JM, Comery TA, Arias R, Bowlby M, Martone R, Morrison JH, Pangalos MN, Reinhart PH, Bloom FE (2006) Earlyonset behavioral and synaptic deficits in a mouse model of Alzheimer's disease. Proc Natl Acad Sci U S A 103:5161-5166. CrossRef Medline

Jankowsky JL, Xu G, Fromholt D, Gonzales V, Borchelt DR (2003) Environmental enrichment exacerbates amyloid plaque formation in a transgenic mouse model of Alzheimer disease. J Neuropathol Exp Neurol 62:12201227. Medline

Jankowsky JL, Melnikova T, Fadale DJ, Xu GM, Slunt HH, Gonzales V, Younkin LH, Younkin SG, Borchelt DR, Savonenko AV (2005) Environmental enrichment mitigates cognitive deficits in a mouse model of Alzheimer's disease. J Neurosci 25:5217-5224. CrossRef Medline
Jin M, Shepardson N, Yang T, Chen G, Walsh D, Selkoe DJ (2011) Soluble amyloid beta-protein dimers isolated from Alzheimer cortex directly induce Tau hyperphosphorylation and neuritic degeneration. Proc Natl Acad Sci U S A 108:5819-5824. CrossRef Medline

Kawarabayashi T, Younkin LH, Saido TC, Shoji M, Ashe KH, Younkin SG (2001) Age-dependent changes in brain, CSF, and plasma amyloid (beta) protein in the Tg2576 transgenic mouse model of Alzheimer's disease. J Neurosci 21:372-381. Medline

Kayed R (2010) Anti-tau oligomers passive vaccination for the treatment of Alzheimer disease. Hum Vaccines 6:931-935. CrossRef

Kayed R, Head E, Thompson JL, McIntire TM, Milton SC, Cotman CW, Glabe CG (2003) Common structure of soluble amyloid oligomers implies common mechanism of pathogenesis. Science 300:486-489. CrossRef Medline

Kayed R, Head E, Sarsoza F, Saing T, Cotman CW, Necula M, Margol L, Wu J, Breydo L, Thompson JL, Rasool S, Gurlo T, Butler P, Glabe CG (2007) Fibril specific, conformation dependent antibodies recognize a generic epitope common to amyloid fibrils and fibrillar oligomers that is absent in prefibrillar oligomers. Mol Neurodegener 2:18. CrossRef Medline

Kim SH, Tang YP, Sisodia SS (2006) Abeta star: a light onto synaptic dysfunction? Nat Med 12:760-761; discussion 761. CrossRef Medline

Kotilinek LA, Bacskai B, Westerman M, Kawarabayashi T, Younkin L, Hyman BT, Younkin S, Ashe KH (2002) Reversible memory loss in a mouse transgenic model of Alzheimer's disease. J Neurosci 22:6331-6335. Medline

Larson M, Sherman MA, Amar F, Nuvolone M, Schneider JA, Bennett DA, Aguzzi A, Lesné SE (2012) The complex PrP(c)-Fyn couples human oligomeric Abeta with pathological tau changes in Alzheimer's disease. J Neurosci 32:16857-16871a. CrossRef Medline

Lasagna-Reeves CA, Castillo-Carranza DL, Guerrero-Muoz MJ, Jackson GR, Kayed R (2010) Preparation and characterization of neurotoxic tau oligomers. Biochemistry 49:10039-10041. CrossRef Medline

Lasagna-Reeves CA, Castillo-Carranza DL, Jackson GR, Kayed R (2011a) Tau oligomers as potential targets for immunotherapy for Alzheimer's disease and tauopathies. Curr Alzheimer Res 8:659-665. CrossRef Medline

Lasagna-Reeves CA, Castillo-Carranza DL, Sengupta U, Clos AL, Jackson GR, Kayed R (2011b) Tau oligomers impair memory and induce synaptic and mitochondrial dysfunction in wild-type mice. Mol Neurodegener 6:39. CrossRef Medline

Lasagna-Reeves CA, Castillo-Carranza DL, Sengupta U, Sarmiento J, Troncoso J, Jackson GR, Kayed R (2012a) Identification of oligomers at early stages of tau aggregation in Alzheimer's disease. FASEB J 26:1946-1959. CrossRef Medline

Lasagna-Reeves CA, Castillo-Carranza DL, Sengupta U, Guerrero-Munoz MJ, Kiritoshi T, Neugebauer V, Jackson GR, Kayed R (2012b) Alzheimer brain-derived tau oligomers propagate pathology from endogenous tau. Sci Rep 2:700. CrossRef Medline

Lesné SE (2013) Breaking the code of amyloid- $\beta$ oligomers. Int J Cell Biol 2013:950783. CrossRef Medline

Lesné S, Koh MT, Kotilinek L, Kayed R, Glabe CG, Yang A, Gallagher M, Ashe $\mathrm{KH}$ (2006) A specific amyloid-beta protein assembly in the brain impairs memory. Nature 440:352-357. CrossRef Medline

Lesné S, Kotilinek L, Ashe KH (2008) Plaque-bearing mice with reduced levels of oligomeric amyloid-beta assemblies have intact memory function. Neuroscience 151:745-749. CrossRef Medline

Maia LF, Kaeser SA, Reichwald J, Hruscha M, Martus P, Staufenbiel M, Jucker M (2013) Changes in amyloid-beta and Tau in the cerebrospinal fluid of transgenic mice overexpressing amyloid precursor protein. Sci Transl Med 5:194re192. CrossRef Medline

Miller EC, Teravskis PJ, Dummer BW, Zhao X, Huganir RL, Liao D (2014) Tau phosphorylation and tau mislocalization mediate soluble Abeta oligomer-induced AMPA glutamate receptor signaling deficits. Eur J Neurosci 39:1214-1224. CrossRef Medline

Morgan D, Diamond DM, Gottschall PE, Ugen KE, Dickey C, Hardy J, Duff K, Jantzen P, DiCarlo G, Wilcock D, Connor K, Hatcher J, Hope C, Gordon M, Arendash GW (2000) A beta peptide vaccination prevents memory loss in an animal model of Alzheimer's disease. Nature 408:982985. CrossRef Medline

Noda-Saita K, Terai K, Iwai A, Tsukamoto M, Shitaka Y, Kawabata S, Okada M, Yamaguchi T (2004) Exclusive association and simultaneous appearance of congophilic plaques and AT8-positive dystrophic neurites in 
Tg2576 mice suggest a mechanism of senile plaque formation and progression of neuritic dystrophy in Alzheimer's disease. Acta Neuropathol 108:435-442. CrossRef Medline

Nussbaum JM, Schilling S, Cynis H, Silva A, Swanson E, Wangsanut T, Tayler K, Wiltgen B, Hatami A, Rönicke R, Reymann K, Hutter-Paier B, Alexandru A, Jagla W, Graubner S, Glabe CG, Demuth HU, Bloom GS (2012) Prion-like behaviour and tau-dependent cytotoxicity of pyroglutamylated amyloid-beta. Nature 485:651-655. CrossRef Medline

Oddo S, Caccamo A, Kitazawa M, Tseng BP, LaFerla FM (2003) Amyloid deposition precedes tangle formation in a triple transgenic model of Alzheimer's disease. Neurobiol Aging 24:1063-1070. CrossRef Medline

Oddo S, Vasilevko V, Caccamo A, Kitazawa M, Cribbs DH, LaFerla FM (2006) Reduction of soluble Abeta and tau, but not soluble Abeta alone, ameliorates cognitive decline in transgenic mice with plaques and tangles. J Biol Chem 281:39413-39423. CrossRef Medline

Rapoport M, Dawson HN, Binder LI, Vitek MP, Ferreira A (2002) Tau is essential to beta-amyloid-induced neurotoxicity. Proc Natl Acad Sci U S A 99:6364-6369. CrossRef Medline

Rasool S, Martinez-Coria H, Wu JW, LaFerla F, Glabe CG (2013) Systemic vaccination with anti-oligomeric monoclonal antibodies improves cognitive function by reducing Abeta deposition and tau pathology in 3xTg-AD mice. J Neurochem 126:473-482. CrossRef Medline

Reed MN, Hofmeister JJ, Jungbauer L, Welzel AT, Yu C, Sherman MA, Lesné S, LaDu MJ, Walsh DM, Ashe KH, Cleary JP (2011) Cognitive effects of cell-derived and synthetically derived Abeta oligomers. Neurobiol Aging 32:1784-1794. CrossRef Medline

Roberson ED, Scearce-Levie K, Palop JJ, Yan F, Cheng IH, Wu T, Gerstein H, Yu GQ, Mucke L (2007) Reducing endogenous tau ameliorates amyloid beta-induced deficits in an Alzheimer's disease mouse model. Science 316:750-754. CrossRef Medline

Rozenstein-Tsalkovich L, Grigoriadis N, Lourbopoulos A, Nousiopoulou E, Kassis I, Abramsky O, Karussis D, Rosenmann H (2013) Repeated immunization of mice with phosphorylated-tau peptides causes neuroinflammation. Exp Neurol 248:451-456. CrossRef Medline

Santacruz K, Lewis J, Spires T, Paulson J, Kotilinek L, Ingelsson M, Guimaraes A, DeTure M, Ramsden M, McGowan E, Forster C, Yue M, Orne J, Janus C, Mariash A, Kuskowski M, Hyman B, Hutton M, Ashe KH (2005) Tau suppression in a neurodegenerative mouse model improves memory function. Science 309:476-481. CrossRef Medline

Sarsoza F, Saing T, Kayed R, Dahlin R, Dick M, Broadwater-Hollifield C, Mobley S, Lott I, Doran E, Gillen D, Anderson-Bergman C, Cribbs DH, Glabe C, Head E (2009) A fibril-specific, conformation-dependent antibody recognizes a subset of Abeta plaques in Alzheimer disease, Down syndrome and Tg2576 transgenic mouse brain. Acta Neuropathol 118: 505-517. CrossRef Medline

Selkoe DJ (2001) Alzheimer's disease: genes, proteins, and therapy. Physiol Rev 81:741-766. Medline

Shankar GM, Li S, Mehta TH, Garcia-Munoz A, Shepardson NE, Smith I, Brett FM, Farrell MA, Rowan MJ, Lemere CA, Regan CM, Walsh DM, Sabatini BL, Selkoe DJ (2008) Amyloid-beta protein dimers isolated directly from Alzheimer's brains impair synaptic plasticity and memory. Nat Med 14:837-842. CrossRef Medline

Small SA, Duff K (2008) Linking Abeta and tau in late-onset Alzheimer's disease: a dual pathway hypothesis. Neuron 60:534-542. CrossRef Medline

Sokolow S, Henkins KM, Bilousova T, Miller CA, Vinters HV, Poon W, Cole GM, Gylys KH (2012) AD synapses contain abundant Abeta monomer and multiple soluble oligomers, including a 56-kDa assembly. Neurobiol Aging 33:1545-1555. CrossRef Medline

Spires TL, Meyer-Luehmann M, Stern EA, McLean PJ, Skoch J, Nguyen PT, Bacskai BJ, Hyman BT (2005) Dendritic spine abnormalities in amyloid precursor protein transgenic mice demonstrated by gene transfer and intravital multiphoton microscopy. J Neurosci 25:7278-7287. CrossRef Medline

Spires-Jones TL, Meyer-Luehmann M, Osetek JD, Jones PB, Stern EA, Bacskai BJ, Hyman BT (2007) Impaired spine stability underlies plaquerelated spine loss in an Alzheimer's disease mouse model. Am J Pathol 171:1304-1311. CrossRef Medline

Sturchler-Pierrat C, Abramowski D, Duke M, Wiederhold KH, Mistl C, Rothacher S, Ledermann B, Bürki K, Frey P, Paganetti PA, Waridel C, Calhoun ME, Jucker M, Probst A, Staufenbiel M, Sommer B (1997) Two amyloid precursor protein transgenic mouse models with Alzheimer disease-like pathology. Proc Natl Acad Sci U S A 94:13287-13292. CrossRef Medline

Theunis C, Crespo-Biel N, Gafner V, Pihlgren M, López-Deber MP, Reis P, Hickman DT, Adolfsson O, Chuard N, Ndao DM, Borghgraef P, Devijver H, Van Leuven F, Pfeifer A, Muhs A (2013) Efficacy and safety of a liposome-based vaccine against protein Tau, assessed in tau.P301L mice that model tauopathy. PLoS One 8:e72301. CrossRef Medline

Troquier L, Caillierez R, Burnouf S, Fernandez-Gomez FJ, Grosjean ME, Zommer N, Sergeant N, Schraen-Maschke S, Blum D, Buee L (2012) Targeting phospho-Ser422 by active Tau Immunotherapy in the THYTau 22 mouse model: a suitable therapeutic approach. Curr Alzheimer Res 9:397-405. CrossRef Medline

Walls KC, Ager RR, Vasilevko V, Cheng D, Medeiros R, LaFerla FM (2014) p-Tau immunotherapy reduces soluble and insoluble tau in aged 3xTg-AD mice. Neurosci Lett 575:96-100. CrossRef Medline

Westerman MA, Cooper-Blacketer D, Mariash A, Kotilinek L, Kawarabayashi T, Younkin LH, Carlson GA, Younkin SG, Ashe KH (2002) The relationship between Abeta and memory in the Tg2576 mouse model of Alzheimer's disease. J Neurosci 22:1858-1867. Medline

Wilcock DM, Rojiani A, Rosenthal A, Levkowitz G, Subbarao S, Alamed J, Wilson D, Wilson N, Freeman MJ, Gordon MN, Morgan D (2004) Passive amyloid immunotherapy clears amyloid and transiently activates microglia in a transgenic mouse model of amyloid deposition. J Neurosci 24:6144-6151. CrossRef Medline

Yanamandra K, Kfoury N, Jiang H, Mahan TE, Ma S, Maloney SE, Wozniak DF, Diamond MI, Holtzman DM (2013) Anti-tau antibodies that block tau aggregate seeding in vitro markedly decrease pathology and improve cognition in vivo. Neuron 80:402-414. CrossRef Medline

Zempel H, Mandelkow EM (2012) Linking amyloid-beta and tau: amyloidbeta induced synaptic dysfunction via local wreckage of the neuronal cytoskeleton. Neurodegener Dis 10:64-72. CrossRef Medline

Zempel H, Thies E, Mandelkow E, Mandelkow EM (2010) Abeta oligomers cause localized $\mathrm{Ca}(2+)$ elevation, missorting of endogenous Tau into dendrites, Tau phosphorylation, and destruction of microtubules and spines. J Neurosci 30:11938-11950. CrossRef Medline 